\title{
Vectors of educational change: An introduction to the twentieth anniversary issue of the Journal of Educational Change
}

\author{
Dennis Shirley ${ }^{1}$
}

Published online: 13 August 2020

(c) Springer Nature B.V. 2020

\begin{abstract}
This article introduces a special, 20th anniversary issue of the Journal of Educational Change. The special issue edictoras have organized significant international contributions to theory-building into three areas. These concern diverse modalities of educators' professionalism, debates around "getting to scale" with successful innovations, and conflicting views of social justice in schools and societies. Each of these areas comprises an independent vector of disagreement and debate, with differing meaning and interpretations based upon the cultures and histories of the given systems under review. The article asks what kinds of new research, and what kinds of affiliated theories in these topic areas, can best help to move the field of educational change forward in the coming years.
\end{abstract}

Keywords Professionalism $\cdot$ Change $\cdot$ Reform $\cdot$ Social justice

Twenty years ago, Founding Editor Andy Hargreaves launched the Journal of Educational Change from the Ontario Institute for Studies in Education at the University of Toronto. It was a bright beacon of hope at the time. After years of slogging away in the salt mines of school improvement, it seemed that reformers had reached a cul-de-sac. We needed some new ways of thinking to move our work forward, and the Journal looked like just the promising venue for publishing research and sponsoring debates that the times demanded.

It was a personal matter for some of us. I had been studying community organizing for educational change in inner city schools in Texas for over a decade and had seen evidence of a promising new model of conjoint school and community uplift (Shirley 1997, 2002). Just as real momentum was being established with many of these schools, however, new regimes of accountability intensified beyond what

Dennis Shirley

dennis.shirley@bc.edu

1 Boston College, Chestnut Hill, USA 
anyone had imagined when state-wide testing was introduced in the US in the 1980s. Standards were promulgated with increasing force. Exit options like charter schools in the US and academies in the UK spread like wild-fire. The traditional grammar of schooling (Tyack and Tobin 1994), was back with a vengeance.

Such phenomena now have been documented in tens of thousands of schools in the US and beyond. Accountability pressures provided new rationales for educators to return to forms of frontal instruction and curriculum delivery that innovators had sought to surpass with more active, student-initiated forms of learning. As evidence accumulated, many began to suspect that it was no longer a matter of tinkering here and there to upgrade the new reforms, some of which we had tacitly supported, but rather of critically interrogating them. It became important to determine what the purpose of education was in the first place, and then to assess whether the new reforms were attaining espoused goals or distracting from them. This became an increasingly moral imperative as surveys and teacher retention data showed that educators themselves were increasingly disenchanted with what was transpiring under the name of "reform," while the ratcheting up of pressure and sanctions produced at best modest results.

At times, it began to feel that the entire enterprise of public education was under siege. Still, those of us working away in the proverbial "trenches" knew that the problems in schools had predated recent reforms. Many issues couldn't be pushed off on policy makers. Some of the most tenacious problems-outdated teaching strategies, poorly designed curricula, tracking, and unfair assessments that discriminated against the poor, the learning disabled, and students of color-were squarely within the locus of control of the profession. These would have to be confronted and resolved by educators themselves.

In this regard the Journal of Educational Change, in its different iterations over two decades, has endeavored to stake out an independent position on contemporary educational issues while at the same time being open to all kinds of dissenting perspectives. In a retrospective review of the first 14 years of the Journal published in 2017, Juan Cristobal García-Huidobro and his colleagues identified 5 periods in the Journal's history that reflected the major transformations in the field. In the first of these, "assumed universality in educational change," from 2000 to 2002, Journal authors wrote with enthusiasm about learning across borders and its potential for improving the human condition. This was followed by a second phase from 2003 to 2005, emphasizing "equity and context" in diverse jurisdictions. From 2006 to 2008 the Journal published numerous articles on international large-scale assessments. In the next phase, from 2009 to 2011, articles conveying predominantly "Anglo-American skepticism" prevailed. Finally, a fifth phase from 2012 to 2014 ensued of "emergent internationalization and empiricism.” (García-Huidobro et al. 2017, pp. 270).

There is real value in this type of literature review. The historical periodization rings true, and helps readers to understand where the field has been in order to ascertain where we might go next. Still, there is a danger that subtle but important differences of opinion could be overlooked in the formulation of generalizations.

Mindful of tendencies towards groupthink that can inhibit even the best of journals, incoming Editor Corrie Stone-Johnson and I have wanted to do something different with this twentieth anniversary issue of the Journal. We have sought out 
authors we believed could make significant contributions to theory-building and have clustered their topics into three areas. These are:

1. Educators' professionalism In what does it reside, and how is it evolving over time?

2. Getting to scale Once a successful change model is identified, how we can ensure that it is accessible to each and every learner who could benefit from its approach.

3. Justice Given the striking inequalities evident in almost all school systems in almost all countries, what can educators do to contribute to teach and empower those students who are most needful of a quality education?

Consider each one of these topics-educators' professionalism, getting to scale, and justice - to constitute an independent vector of disagreement and debate. What kinds of new research, and what kinds of affiliated theories in these topic areas, can best help us to move the field of educational change forward?

\section{Vector one: Educators' professionalism}

The first vector pertains to debates about the meaning and import of educators' professionalism. Our opening article in this special issue is written by Andy Hargreaves, the Editor-in-Chief of the Journal for its first 11 years. In it, Hargreaves draws upon new data from Ontario, Canada, to argue that it isn't simply the case that high-stakes testing is damaging to pupil learning. This has been done many times. What is new here is that Hargreaves argues that even mid-stakes testing has deleterious effects. Ontario tests its students at grades 3, 6, and 9, and it is precisely at those grade levels where educators report the least innovation and the most traditional forms of instruction prevail. While students at other grade levels can flourish, and their teachers enjoy far-reaching professional discretion, students in those 3 grade levels are subjected to the most anachronistic forms of rote learning and memorization. This is done even though teachers themselves know that they could do better, which makes for an insidious form of compliance in one's own de-professionalization. If Ontario wishes to maintain its position as a global leader of educational change, Hargreaves argues, it is time to abolish its mid-stakes testing system and to restore the professional integrity of its educators across the system.

What might come after testing? In her essay entitled "Creating Capacity for Learning-Are We There Yet?," Louise Stoll invites us to reposition learning as the central purpose of schools. This might seem so obvious as to go without saying. Still, the challenges of "low trust and punitive accountability" in schools often provokes defensive reactions among educators that counteract the deep and mindful teaching and learning of which we are capable (Shirley and MacDonald 2017). "Spirals of inquiry" (Halbert and Kaser 2013) provide one way of thinking collectively about learning, rather than public relations management, as the core moral purpose of schools. 
While open to engaging with the kinds of concerns espoused by Hargreaves and Stoll, Amanda Datnow, my predecessor as Editor-in-Chief of the Journal of Educational Change, suggests that an intermediate strategy that draws upon data selectively but is not enslaved to it, could be explored by teachers in more schools. Drawing upon her research with Vicki Park (2019), Datnow argues that much potentially useful data often is not studied by teachers in any meaningful way, because they do know how to leverage it to improve their teaching. She finds that when teachers have adequate professional development, administrative support, and collaborative opportunities with colleagues, that data can take their rightful place in a broad portfolio of materials that teachers can use to improve their instruction and to lift their students' learning results. While scholars should be rightfully critical of an overemphasis upon testing and accountability systems, then, there is no inherent reason why teachers should fail to draw upon relevant findings, especially when these can help those students who need assistance most to get on with their learning. The heart of the matter is "professional collaboration with purpose" driven by a genuine "mindset of learning" rather than a soulless "bureaucratic task or an overly linear model of instructional improvement."

Like Datnow, Jenny Weiner acknowledges problems with testing yet still wishes to preserve what she sees as some benefits of testing and accountability. Her research supports the findings of incoming Journal Editor Corrie StoneJohnson that younger teachers as a generational cohort don't especially mind testing, and even find their older colleagues' preoccupation with its negative features rather quaint and eccentric. Weiner calls these educators' approach a new form of "nuanced professionalism" that is superseding an older variant of "occupational professionalism." This new form of professionalism recognizes that teachers' autonomy has sometimes been abused in the past by those unwilling or unable to put in the long hard hours planning lessons, managing unruly students, and grading assignments. Observing these problems, younger educators appear to be willing to trade off some kinds of discretion in favor of a more collective way of conducting work, even if this entails some top-down direction from time to time. As Weiner points out, her perspective is similar to Stone-Johnson's description of a "parallel professionalism" (2014, p. 749) in which educators find standards and curriculum frameworks to be useful points of reference that relieve them of the burden of planning everything from scratch day-in and day-out.

The differences between the findings of Hargreaves and Stoll on the one hand, and Datnow and Weiner on the other, indicate that a range of opinions on the essence of educators' professionalism can be found in the Journal of Educational Change. While there is a shared concern for ongoing transformations in teachers' work, the findings point in different directions when it comes to how policy should be understood and negotiated in situ in the schools. The differences should not be overstated, but they should be noted and taken as points of departure for further research. It is perhaps not accidental that in addition to different perspectives, the lines of division here reflect different" generational interpretive frameworks" (Stone-Johnson 2016, p. 12). 


\section{Vector two: Getting to scale}

A second vector of disagreement can be found regarding the topic of spreading educational change. In 2016 Santiago Rincón-Gallardo and Brahm Fleisch brought together a truly global ensemble of articles for a Special Issue of the Journal on the topic of "Bringing Effective Instructional Practice to Scale." The underlying concept of the Special Issue was to "bring together original articles and scholars who have developed and/or studied relatively successful approaches to large scale instructional change in a variety of contexts." (Rincón-Gallardo and Fleisch 2016, p. 380). These included Colbert and Arboleda (2016), writing on the Escuela Nueva movement in Colombia; Banerji and Chavan (2016) writing about literacy reforms in India; and Rincón-Gallardo and Fleisch themselves, reporting on their findings on education as a social movement in Mexico and the teaching of reading in South Africa respectively. It was a fascinating Special Issue, not the least because the author credited with the notion of "getting to scale," Richard Elmore, wrote a blistering critique of his own concept as marked by "unthinkable presumptuousness and naivete," in an afterward to the volume (Elmore 2016, p. 529).

Hang Minh Le would be likely to agree with Elmore on the dangers of thinking in terms of "getting to scale," especially when it comes to the dissemination of reform models internationally. In her article on "Where be the 'Magic Bullet' for Educational Change? Vietnam and the Quest of Policy Borrowing from Abroad" in this issue, Le criticizes the tendency of policy makers in the global South to seek solutions from other countries rather than on developing indigenous capacity to address educational challenges. She asserts that a "coloniality of knowledge production" influences policy makers, who are controlled in many ways by transnational funders such as the World Bank.

Le finds that this influence of coloniality is so powerful that even highly successful grass-roots mobilizing efforts in the global South, such as the Escuela Nueva movement in Colombia, that have been recognized for their achievements by the Yidan Prize in Hong Kong and the WISE prize in Qatar, are complicit in the oppressive legacy of colonialism. For Vietnamese educational reformers, the attraction to Escuela Nueva appears to reside in its adaptation of western educational ideals such as student-centered classrooms, active learning, and parent and community engagement. For Le, these are not universal features of good teaching and learning. They are manifestations of western values that should not be imposed on Vietnam, however attractive they might appear to policy makers eager to make their mark as effective educational leaders. Since Vietnam already scores very highly on the OECD's PISA tests, she notes, it hardly needs to engage in the "fast policy making still rooted in coloniality" that is common in much of the Global South.

Le's analysis of Escuela Nueva would appear to offer a critique of the enthusiasm expressed by Rincón-Gallardo for this model of educational change recently in his book (2019) entitled Liberating Learning. In his article in this special issue, Rincón-Gallardo draws upon his leadership and research with the "learning 
communities" approach developed by Gabriel Cámara and his colleagues in remote rural middle schools in Mexico, which shares many affinities with Escuela Nueva. He asks that greater scholarly attention be devoted to reform efforts such as these two Latin American examples as well as "Activity Based Learning" in India and Community Schools in Egypt. These diverse efforts, he argues, are "more similar in their genesis and development to social movements than to conventional education programs or policies." Taken together, they present a "feasible alternative" to the default culture of schooling that has been exported by the Global North and imposed upon the Global South.

Brahm Fleisch, for his part, expresses no particular concerns about strong stateled initiatives to improve education in the Global South. He argues that western commentators generally have failed to acknowledge the contributions of vigorous, top-down leadership to "systems as diverse as Hong Kong, Singapore, Korea, Japan, Shanghai, and Vietnam." Fleisch might agree with Le that the sensitivity of educators from the "Anglosphere" of the Global North for child-centered pedagogies, project-based learning, and teacher autonomy has little relevance for countries endeavoring to extricate themselves from the powerful legacies of colonialism. Instead, Fleisch sees value in "strong central control" by governments motivated by "strong egalitarian impulses."

From this perspective, Elmore's retraction of the concept of "getting to scale" is overstated. Whether through the kinds of confidence-building, state-led leadership strategies favored by Fleisch, or the bottom-up social movements described by Rincón-Gallardo, educators have moral obligations and professional responsibilities to engage with all kinds of diverse populations to promote learning to enhance the human condition. Even Le's criticism of policy borrowing from one nation of the Global South to another could be seen as an admonition to practice "getting to scale" with Indigenous philosophies and practices within Vietnam. Self-criticism is good. Self-paralysis is not.

\section{Vector three: Justice}

Finally, a third vector of disagreement may be found in conceptualizations of justice in educational change. Helen Janc Malone argues for community schools as expressions of social justice that help schools to "engage in diverse intentional partnerships, authentic grassroots family and community engagement, and collaborative governance and leadership structures." While many have argued that we each now live in a "deterritorialized context" (Appadurai 1996, p. 37) with a concomitant "decline of the local" (Foster 2004, p. 476), Malone sees local communities as indispensable educational resources, especially for equity purposes, as "funds of knowledge" (Moll et al. 1992) ordinarily bracketed out of schools are appropriated for learning. However much we have come to rely on our cell phones and the Internet, in the end we are all embodied and need contact with other human beings unmediated by technological tools. Given the unprecedented disruptive power of the coronavirus, many would agree that local communities and their schools have proven themselves to be more crucial than ever. 
Alison Skerrett, on the other hand, asks educators to consider how they are serving growing numbers of transnational students, who, "through a mixture of necessity and choice, live their lives across two or more countries." She calls for a "transnationally-inclusive approach to literacy education" as an expression of social justice, that could help students to understand their different languages and distinctive cultural blends as assets rather than deficits. Since educational systems are bound up with concepts of nation-building, Skerrett sees formidable obstacles for the future of transnational education. She cites research by Hamann and Zuñiga (2011) showing that it nonetheless is possible to blend transnational identity formation for youth with nations' legitimate concerns to educate students capable of thriving within their given geographical boundaries.

Can we find a way to combine the social justice concerns for community schools advanced by Malone and the similar values upheld by Skerrett for transnational students? One promising case is provided by Franco-Ontarian educators in Canada who have found new ways to blend their traditional and endangered language minority culture with a new transnational population of French-speaking students from countries as diverse as Haiti, Senegal, Cameroon, and France itself (Shirley and Hargreaves 2020). By building strong interdisciplinary teams of educators, including staff with expertise in cultural diversity, linguistics, and curriculum development, these educators have shown that an inclusive and creative approach to all of our diverse students can indeed be forged which creates a new kind of community appropriate to our current circumstances. We need not make a forced choice between local community and transnational students, then. As educators, we have the collective intelligence and can marshal the willpower to forge new kinds of learning communities that are as diverse and culturally rich as the students we find before us.

\section{Conclusion}

In its first 20 years, the Journal of Educational Change has served as a fulcrum for fascinating debates on many more topics than the themes of professionalism, getting to scale, and social justice than are featured in this Special Issue. As of this writing (June 2020) the world is in the grip of a global pandemic that has killed more than 350,000 people and infected more than 5 million others. Nine out of 10 children worldwide have been kept home from school. Millions of these had no internet access at the time, depriving them of access to educational resources even as others, more fortunate, bounded ahead. Unemployment leapt off the charts to its highest levels since the Great Depression in many countries, and food insecurity soared.

At the same time as dark clouds loomed, silver linings could be detected. Some students genuinely liked learning at home, free from the distractions of disruptive classmates and ill-timed interruptions to instruction. While many apps designed to promote learning were poorly designed, others were exciting and they connected students with new digital friends from around the world. Nature rebounded as flights and commutes to and from work ground to a halt. Random acts of kindness popped up in unlikely places. Many agreed that they now were taking each other less for granted. Now and then it was possible to glimpse a better future. 
The Journal of Educational Change has a role to play in shaping that better future. In its 20 years, it has forged bold new spaces for debates on professionalism, "getting to scale," change, and social justice. The coronavirus pandemic is just one signal that the scope of these debates has ample new room for development in the years to come. In this, my final introductory essay for the Journal, I ask that all of us affiliated with the Journal-its board members, authors, and reviewers_-provide our wholehearted support to incoming Editor-in-Chief Corrie Stone-Johnson.

\section{References}

Appadurai, A. (1996). Modernity at large: Cultural dimensions of globalization. Minneapolis: University of Minnesota Press.

Banerji, R., \& Chavan, M. (2016). Improving literacy and math instruction at scale in India's primary schools: The case of Pratham's Read India program. Journal of Educational Change, 17(4), 453-476.

Colbert, V., \& Arboleda, J. (2016). Bringing a student-centered participatory pedagogy to scale in Colombia. Journal of Educational Change, 17(4), 385-410.

Datnow, A., \& Park, V. (2019). Data-driven leadership. San Francisco: Jossey-Bass.

Elmore, R. (2016). "Getting to scale ..." It seemed like a good idea at the time. Journal of Educational Change, 17(4), 529-537.

Foster, W. P. (2004). The decline of the local: A challenge to educational leadership. Educational Administration Quarterly, 40(2), 176-191.

Halbert, J., \& Kaser, L. (2013). Spirals of inquiry for equity and quality. Vancouver: BCPVPA Press.

Hamann, E. T., \& Zuñiga, V. A. (2011). Schooling and the everyday ruptures transnational children encounter in the United Sttes and Mexico. In C. Coe, R. R. Reynolds, D. A. Boehm, J. M. Hess, \& H. Rae-Espinoza (Eds.), Everyday ruptures: Children, youth, and migration in global perspective (pp. 141-160). Nashville, TN: Vanderbilt University Press.

Moll, L. C., Amanti, C., Neff, D., \& Gonzalez, N. (1992). Funds of knowledge for teaching: Using a qualitative approach to connect homes and classrooms. Theory into Practice, 31, 132-141.

Rincón-Gallardo, S. (2019). Liberating learning: Educational change as social movement. New York: Routledge.

Rincón-Gallardo, S., \& Fleisch, B. (2016). Bringing effective instructional practice to scale: An introduction. Journal of Educational Change, 17(4), 379-383.

Shirley, D. (1997). Community organizing for urban school reform. Austin, TX: University of Texas Press.

Shirley, D. (2002). Valley Interfaith and school reform: Organizing for power in South Texas. Austin, TX: University of Texas Press.

Shirley, D., \& Hargreaves, A. (2020). Student engagement: Beyond relevance, technology, and fun. Indianapolis, IN: Solution Tree.

Shirley, D., \& MacDonald, E. (2017). The mindful teacher (2nd ed.). New York: Teachers College Press.

Stone-Johnson, C. (2014). Parallel professionalism in an era of standardization. Teachers and Teaching, 20(1), 74-91.

Stone-Johnson, C. (2016). Generational identity, educational change, and school leadership. New York: Routledge.

Tyack, D., \& Tobin, W. (1994). The "grammar" of schooling: Why is it so hard to change? American Educational Research Journal, 31(3), 453-479.

Publisher's Note Springer Nature remains neutral with regard to jurisdictional claims in published maps and institutional affiliations. 